\title{
Local community perceptions of conservation policy: rights, recognition and reactions
}

\author{
Marketta Vuolal and Aili Pyhälä"
}

\author{
Correspondence: \\ Marketta Vuola \\ University of Helsinki \\ Helsinki, Finland \\ Email: marketta.vuola@alumni.helsinki.fi
}

\begin{abstract}
Biodiversity conservation in post-colonial contexts typically takes the form of state-imposed protected areas. Such conservation strategies, especially when failing to involve local communities, have resulted in conflicts between protected area managers and local communities, thereby diminishing conservation effectiveness. This research examines local community institutions, perceptions, and involvement with regard to the management of Ranomafana National Park, South-Eastern Madagascar. Data was collected at the end of 2014 in five case study villages around the park. Our findings indicate that imposed protected area regulations have provoked a wide range of mostly negative reactions amongst local villagers, largely due to lack of communication and negotiation on the part of protected area managers. What few attempts have been made to involve local communities in conservation and development activities have been met with local skepticism and have only served to reinforce existing power asymmetries within local communities. We argue that increasing local autonomy would help to boost local villagers' self-esteem, and enable local communities to have a more equal playing field for future negotiations with conservation authorities. Furthermore, this would also likely trigger more local interest, initiative, and ownership with regards to conservation. Although the Ranomafana National Park area is currently regarded by many local villagers as illegitimate, there is widespread willingness across all five communities to collaborate with conservation authorities, presenting enormous potential for more successful conservation; potential that - at least to date - remains untapped
\end{abstract}

\section{RÉSUMÉ}

Conserver la biodiversité dans un contexte postcolonial se matérialise généralement sous forme de zones protégées établies par I'État. Cependant, ces stratégies de conservation mènent souvent à des conflits entre gestionnaires et communautés locales, affectant en retour leur soutien à la mise en place de zones protégées. Les conservationnistes reconnaissent donc de plus en plus l'importance de considérer l'engagement des communautés locales dans la prise de décisions et la mise en œuvre d'actions de conservation, afin notamment que ces actions soient efficaces.

Cette étude se focalise sur les institutions des communautés locales, leurs perceptions et leur engagement concernant la gestion du Parc National Ranomafana, au Sud-Est de Madagascar. Les données furent collectées à la fin de l'année 2014 dans cinq villages situés autour du parc. Nos résultats indiquent que les réglementations imposées par le parc ont provoqué un large éventail de réactions, principalement négatives, de la part des villageois, dû à un manque de communication et de négociations de la part des gestionnaires du parc.

Les quelques tentatives d'inclusion des communautés locales dans les patrouilles de surveillance du parc n'ont servi qu'à renforcer les asymétries de pouvoir pré-existantes. De même, seulement une petite partie des résidents locaux peuvent bénéficier de la gestion du parc. Les familles les plus vulnérables économiquement continuent à dépendre étroitement de ressources forestières dont l'exploitation est interdite, risquant des sanctions de la part des gestionnaires du parc qui perturbent encore plus la cohésion sociale à l'échelle locale. Les autorités sont en retour réticentes à accorder leur confiance aux villageois. Même si I'on ne peut pas s'attendre à ce que ce cycle de méfiance disparaisse soudainement, les tensions actuelles entre communautés locales et gestionnaires du parc doivent s'estomper si le but est d'obtenir une gestion durable du parc à long-terme.

Nous nous prononçons en faveur d'une plus grande autonomie locale qui permettrait non seulement de développer l'estime de soi des membres de la communauté, mais susciterait également plus d'intérêt et d'appropriation envers les actions de conservation, permettant ainsi aux communautés locales d'être sur un pied d'égalité lors de futures négociations avec les autorités du parc. En conclusion, alors que la zone protégée est majoritairement perçue comme illégitime, il existe une volonté réelle de la part des cinq communautés de collaborer avec les autorités chargées de la conservation, présentant un potentiel énorme - qui

\footnotetext{
I University of Helsinki, Helsinki, Finland

॥ Metapopulation Research Centre, Department of Biosciences, PO Box 65 (Viikinkaari 1), 00014 University of Helsinki, Finland

Citation Vuola, M. and Pyhälä, A. 2016. Local community perceptions of conservation policy: Rights, recognition and reactions. Madagascar Conservation \& Development 11, 2: 77-86. http://dx.doi.org.104314/mcd.v11i2.6
} 


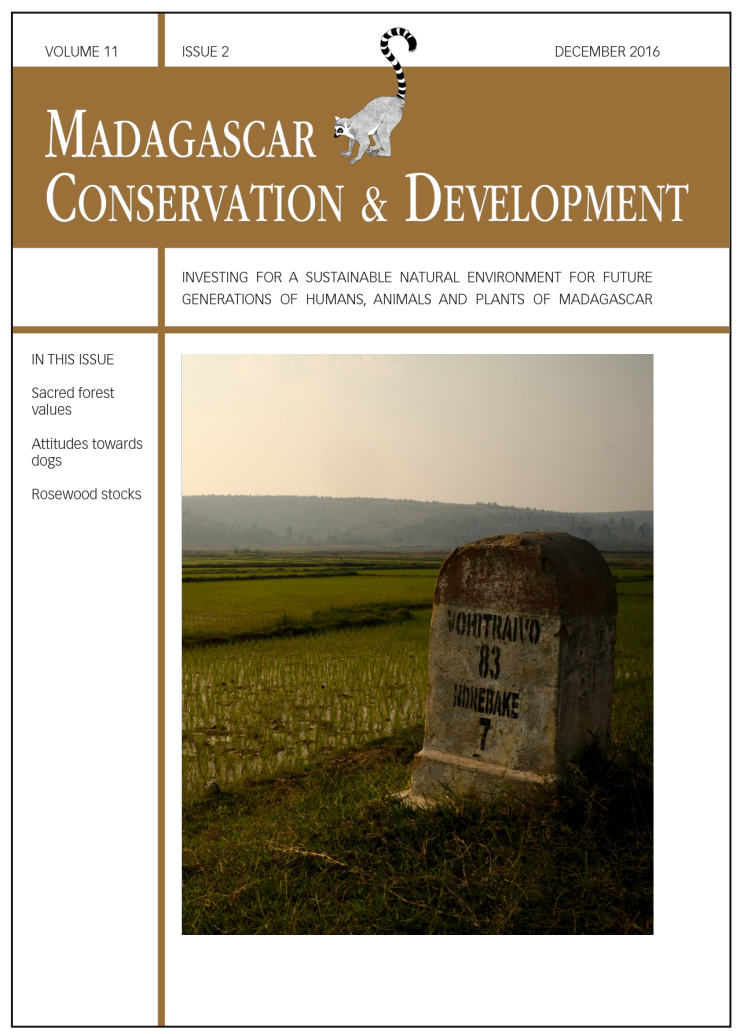

? HKHNHZ] HY 8VUZLY_H[P/U \# 9L_LSMT LU[ $Z$ Z [OL Q Q ] YUHS VMEJKPU @J LHU L( ZP F\$P VM[OZZ RZZ[P] [R/U) DOL_R' Z LAWXLZZLK PU J VU[YP I ] [R/UZ [V ? 89 HML ZV\$\$ [OVZL VMIOL H] [OVYZ HUK UV] [OVZL VMOL Q] YUHSL KPVYZ VY[OL W] I \$ZOLY

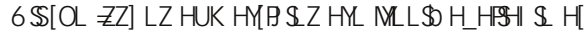
O[[WA,' ' ')Q] YUHS JK)JVT

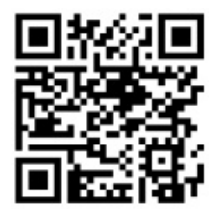

8VU[H] [ $\forall]$ YUHS? 89

PUNW5 Q] YUHST J K)UL[ NWYNLUL YHSPUX] PRRZ YLNHTKPUN? 89 MUKPUN5 Q] YUHS J K)UL[ [V Z] WWWY [OL Q] YUHS

? HKHNHZJ HY8VUZLY_H[R/U \# 9L_LSMTT LU]

$\exists Z[P]$ [L HUK ? ] ZL] T VNG U[OYWWS/ND

EUPLLYZPB VMG] YP O

F RU[LYO] YL YZ[YFZZL . 3-

$8<(2-01 \mathrm{G}) \backslash P \mathrm{O}$

C PCL YSHUK

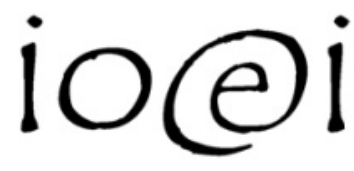

もJRPU @ LHU L( もR

AYT V[REN6 NF HU A] I \$ZORNNHUK : K] J H[RU

' ' ' )R/LRRJJVT

? PZZV] YP7V[HUA HS; HKLU \% 7; \&

? HKHNHZJ HYBLZLHM O HUK 8VUZLY_H[R/U AYVNYTT

$7 \mathrm{~A} / / 3$.

6 U[HUHUHM_V' . . . ' ? HKHNHZ] HY 
reste pour l'instant inexploité - en terme d'amélioration des actions de conservation.

\section{INTRODUCTION}

Madagascar is one of the world's biodiversity hotspots and a priority target for biodiversity conservation with its high rate of endemism, diversity, and level of threats (Myers et al. 2000). One of the major challenges for conservation in Madagascar is the current socio-economic condition: the country is among the ten poorest countries in the world (as measured by GDP per capita) with a large, and rapidly growing, rural population (annual rural population growth of $1.8 \%$ ) that, due to direct livelihood dependence on natural resources, places tremendous pressure on the island's remaining intact ecosystems and habitats (World Bank 2016, data from the year 2014, Aymoz et al. 2013). One of the most commonly proposed solutions has been to establish protected areas (PAs) that exclude local people from further threatening the endangered natural habitats, as in many other contexts worldwide (e.g., Brockington 2002).

In the Global South, PAs are often established in areas that are already inhabited by small-scale rural communities whose livelihood depends largely on the direct subsistence use of natural resources (Adams and Hutton 2007, Mombeshora and Le Bel 2009). This, in practice, usually leads to local populations suddenly finding themselves confronted with a powerful and externally imposed conservation agenda that not only deprives them of some of their natural resource management regimes, but also leaves them with little compensation or benefits (Naughton-Treves et al. 2005, West et al. 2006, Scales 2014). Moreover, local communities tend to pay the highest price for global conservation efforts (Agrawal and Redford 2009). Therefore, protected areas have in many cases resulted in local resistance and rejection (Cox and Elmqvist 1997, Brockington 2004). The strict protected area model has been criticised over the years for being not only unethical towards local community rights (Brockington et al. 2006, Pyhälä et al. 2016), but also costly (Watson et al. 2014). Moreover, the effectiveness of this model has been questioned. While some comparative studies show rather good results for PAs (at least in forest habitat restoration: Geldmann et al. 2013), there are also studies reporting biodiversity decline in a significant percentage of PAs around the world (Laurance et al. 2012). Laurance and colleagues further show that conservation effectiveness is often influenced by what takes place just outside PA borders.

Despite the apparent conflicts, rural livelihoods depend directly on surrounding ecosystems, and local communities are therefore argued to have substantial common interests with conservation planners (Berkes 2004). In other words, at least in theory, it is in the interest of local populations to safeguard those resources upon which their livelihood depends. For instance, Martinez-Alier (2013) points us to a concept that he refers to as 'environmentalism of the poor', which states that in many conflicts concerning large-scale resource extraction or waste disposal, poor people often support the preservation of nature rather than industrial development (Martinez-Alier 2013). Conservationists have sought to tap into these common interests and, already since the 1980s, there has been a gradual move towards more inclusive conservation strategies (Kothari et al. 2013). Indeed, several cases in the academic literature demonstrate that genuine partnerships with local communities offer long-term biodiversity protection while also supporting the wellbeing of local communi- ties (Schwartzman and Zimmerman 2005, Vermeulen and Sheil 2007). Thus, at least in theory, there is a huge lost potential in not building stronger alliances between conservationists and local communities (Redford and Stearman 1993, Brosius and Russell 2003, Berkes 2004). Especially in most tropical low-income countries where local and state institutions tend to be weak, Barret et al. (2001) recommend cooperation and distribution of authority among several local, state, and international institutions.

The conceptual division between humans and nature, deepseated in Western modes of thinking, was reflected in the initial creation of the PA model in the nineteenth century USA and continues to influence much of the global conservation paradigm still today (Adams and Hutton 2007, Mombeshora and Le Bel 2009). This dichotomy between humans and nature is, however, rarely the philosophy held by local communities with regards to humannature relations (Berkes 2004). Comparative studies show significant overlap of high biodiversity and cultural and linguistic diversities developed during the millennia of human-nature interaction (Balée 1994, Maffi 2005). Indeed, local institutions around the world are usually built around the use, allocation, and management of certain resources, and can therefore even be in contradiction with certain goals of modern conservation strategies (Berkes 2004). This may make it challenging for conservation planners to regard local people as allies, and vice versa. Moreover, finding a common language, let alone epistemology or worldview, and defining common objectives that would benefit both stakeholders, is tasking and time-demanding, to say the least.

This paper presents a case study of the Ranomafana National Park (hereon RNP) in South-Eastern Madagascar, from the perspective of the local community. We question what can be learned about local people's own agency and initiative in conservation. In other words, how aligned are local perceptions, aspirations, and realities with externally imposed conservation agendas, and how could the latter be improved so as to work with, not against, local community interests? The study is based on the tenet that, as resource users, local communities have an essential role in shaping conservation outcomes.

We examine the above questions from a lens of political ecology, defining nature conservation as primarily a social and political process, and a matter of human organisation (Brechin et al. 2002, Berkes 2004, Robbins 2012). We base our study on the premise that the strength of human organisation, i.e., the commitment and cooperation of social actors, ultimately defines the success in reaching biodiversity conservation targets (Brechin et al. 2002). According to some scholars, in order for conservation to be effective, it should already in the planning process address the local communities' human dignity (or environmental justice, see schlosberg 2013) and representation in governance as well as how the legitimacy of conservation governance is ensured locally (Brechin et al. 2002, Adams and Hutton 2007). Moreover, understanding natural resource management requires analysing the relationship among institutions at different scales of governance and across formal and informal spheres (Ostrom 1990, Agrawal and Gibson 1999, Leach et al. 1999). While our study is focused at the local community level, we also present an overview and discussion of how conservation actors work and interplay across multiple levels and spheres in Madagascar, including the authority they hold, the rules and norms that guide their action, and the social implications that conservation policies have on the ground. 


\section{CASE STUDY: RANOMAFANA NATIONAL PARK}

Ranomafana National Park (RNP) is located in the regions of Haute Matsiatra and Vatovavy-Fitovinany in the tropical rainforest mountainous range of eastern Madagascar. The local communities have, according to some assessments, settled the area since the late $18^{\text {th }}$ and early $19^{\text {th }}$ centuries (Ferraro and Rakotondrajaona 1992, as cited in Peters 1999). The majority of the residents belong to one of two self-identified ethnic groups, the Tanala and the Betsileo, of which the Tanala inhabit low lands to the east and the Betsileo the highlands to the west of the National Park (Korhonen 2006). These local communities continue to depend primarily on subsistence agriculture and gathering of forest products, including honey, crayfish, and materials for handicrafts (Kari and KorhonenKurki 2013). The rapid rate of population growth continues to place ever more pressure on land and resources, with cultivations expanding to new - including forested - areas.

The RNP project was initiated in 1991 as an integrated conservation-development program funded by USAID, and organized by two U.S. universities (Peters 1998, Hanson 2012). As a part of this process, the Centre ValBio (CVB) was established in 2003 next to the PA. It continues to be a significant actor today with its core missions of facilitating research, reducing poverty and encouraging environmental conservation by developing ecologically sustainable economic development programs in the area. In 1998, the RNP's management shifted to the Malagasy national government, specifically to the ANGAP (Association Nationale pour la Gestion des Aires Protégées), responsible for park management, conservation education, rural development and promotion of ecotourism, and to MICET (Madagascar Institut pour la Conservation des Écosystèmes Tropicaux) who were responsible for facilitating biodiversity research and health projects (Korhonen 2006). Later, ANGAP changed its name to Madagascar National Parks (MNP), who holds full management responsibility over the park today.

Even though MNP claims to include co-management with local communities within its conservation approach (MNP 2014), it has been criticised of centralised planning that has, throughout its history, lacked the effort to address local social, cultural and economic conditions as well as historical ties to land (Peters 1999, Hanson 2012). Peters (1999) describes the disconnect between the creation of RNP and the 160 local villages: many of the remote villages around the park remained unvisited by park managers, even long after park establishment, with some villages even unaware of the creation of the park, let alone its purpose or meaning (Peters 1999). According to Peters, many locals thought that it was "an attempt by the foreigners to take away their land" (Peters 1999: 69). The initial integrated conservation and development approach lacked any official recognition of resident peoples' rights to self-determination, as well as any public debate (ibid.), and these shortcomings inhibited the success of development activities aimed at supporting local communities' wellbeing (Hanson 2012). The imposed conservation policy continues to cause highly uneven distribution of costs and benefits; the restrictions on natural resource use have the greatest impact on local households (Ferraro 2002) and the development initiatives imposed by conservation authorities have resulted in few improvements in Iocal communities' situation (Korhonen 2006).

\section{METHODOLOGY}

The data for this research was collected mainly from field work conducted in November-December 2014 in the Ranomafana re- gion. The five study villages were chosen based on logistical, temporal, and safety limitations - no statistical sampling based on e.g., the distance to RNP or other criteria was possible. Two to four days were spent in each study village as well as one afternoon in the village of Ambatolahy. Prior to the actual data collection in the sample villages, we pilot-tested our interview in the village of Ambodiaviavy (a Tanala village also bordering the park). Free prior informed consent (FPIC) was obtained in all of the villages and with each informant prior to data collection. With the help of CVB, research permits were asked from the study villages before arriving to them. We organised a village meeting upon our arrival at each village, to allow us to explain the purpose of our visit, how we would use the data, their rights to anonymity, and that their participation was completely voluntary. The same was explained in the beginning of each individual interview. Some individuals did in fact choose to opt out of the study, which emphasizes the importance of researchers carrying out FPIC and stressing voluntary participation. Figure 1 presents the study area. The five main study villages are Manokoakora, Amboditanimena, Vohiparara, Ranovao, and Torotosy and the additional study village is Ambatolahy.

The data collection in the study villages included village meetings $(n=5)$, village-level key informants $(n=5)$ and semi-structured interviews with randomly selected residents $(n=44)$. Our goal was to obtain a geographically balanced sample of each village, as much as possible. Therefore, in each village, we visited households in different parts of the community and interviewed as many households as we could, providing of course that each participant was willing to be interviewed. In most households we interviewed one, sometimes two persons. Sometimes we also interviewed individuals outside of their household, if we happened to meet them elsewhere in the village setting. No other criteria were applied to our sampling, other than that we paid close attention to getting as equal a representation of male and female informants as well as different age groups. The interviews and other com-

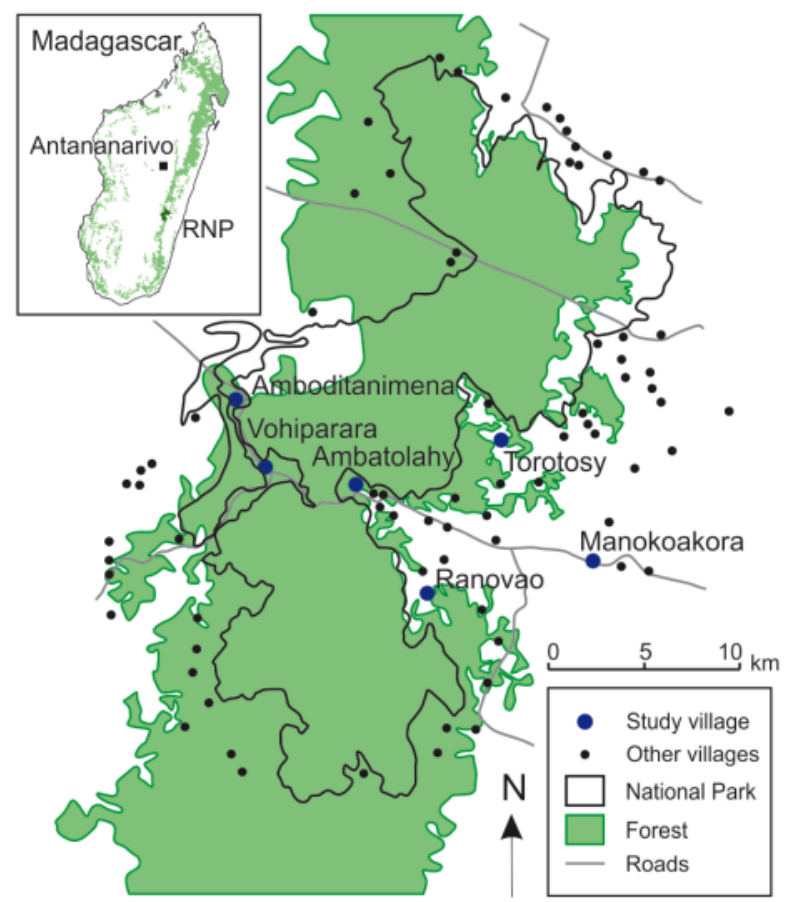

Figure 1. Study area with boundaries of the Ranomafana National Park and locations of the study villages. 
munications were conducted in Malagasy and translated to us by two Malagasy Masters students who were simultaneously carrying out their own fieldwork in collaboration with us (see Acknowledgments).

The interviews were open-ended and semi-structured, with the key thematic points being: social-ecological changes in the area; impacts of RNP on the individual's life; perceptions of RNP and conservation; involvement in, and perspectives on, development and conservation projects and related community associations; rules (formal and informal) and actors related to conservation and natural resource management; possible internal and external conflicts related to conservation and natural resource management, and; their own household's livelihood and agricultural methods.

In addition to interviews, we carried out three focus group discussions $(n=3)$ in the village of Ranovao. Participant observation was carried out throughout the stay in each village in order to validate our findings and provide a general understanding of the way of life and the environmental context. Participant observation included planting rice with the villagers, visiting forest fragments and cultivations surrounding the settlements, and simply spending time with villagers.

In addition to the in-village data collection, a handful of identified experts $(n=5)$ were interviewed in order to gain a wider understanding of the interplay of actors involved in conservation activities and enforcement across levels, as well as to shed light on the broader cultural and political context. We interviewed experts from CVB's Monitoring and Partnership Department and Conservation Education and Outreach Department. They provided us with detailed information about the area, its population and culture, as well as the local conservation and development programs they were implementing. We also interviewed one of the authorities of MNP about the PA management practices and challenges faced, specifically vis-a-vis local communities. We also interviewed two representatives of the Association of Guides of RNP (the actors most directly gaining monetary benefits from conservation). They told us about their perspectives on conservation and the actors involved, and how RNP is benefiting not only them but also their community and other local communities. The final expert interview was with the local police, who told us about the patrolling in the PA and the nature and frequency of illegal activities taking place in the PA.

The village-level interviews, focus group discussions and village meetings were transcribed and analysed using Qualitative Content Analysis (QCA) (e.g., Bazeley 2013). We used codes to label key topics, the attitudes and meanings associated with these topics, and more analytical remarks or conclusions derived from the data. We ended up with 181 specific codes, which in turn were grouped under 22 broader theme codes (e.g., positive/negative/indifferent attitude towards MNP, effects of conservation on livelihoods, views on how the environment should be protected).

Using discourse analysis to unravel the interview material, and systematically coding all topics, the analysis revealed to us a wide range of overlapping and sometimes contradictory views, actors, norms, rules, events, and attitudes related to conservation, natural resources management and land struggles at large, which in turn gave us glimpses into the complex realities, relations and interests at stake - all influencing how local communities feel about RNP management. QCA also served well for bringing up the variety of meanings held by informants (Supplementary Material).

\section{RESULTS}

RNP was implemented with a core area allocated for strict biodiversity preservation, and where human impact is minimised. Harvesting is strictly prohibited but local people are allowed to trespass through the park boundaries. The core area is surrounded by a $2.5 \mathrm{~km}$ wide buffer zone, a mosaic of forest fragments and cultivations. The rules concerning the use of forests along the buffer zone vary. Table 1 summarises these in the case of each study village. Almost no forest areas in the buffer zone are managed by local communities, the exception being one area managed by the village of Vohiparara at the western side of the PA. It has after some struggles managed to obtain from MNP a communitymanaged forest of 25 hectares. The villagers use the forest e.g., for gathering of non-timber forest products, collecting wood for fire and construction, and for rituals.

In contrast, the history of Amboditanimena, only five kilometres from Vohiparara, is somewhat different, namely one of forced relocation. The people of Amboditanimena reported that soon before the establishment of the RNP, the community had relocated to wetland valleys within the PA, where they lived and cultivated rice paddies. When the RNP was established in 1991, they were promised that they could continue cultivating in the $2.5 \mathrm{~km}$ wide buffer zone but, to the surprise of the villagers, in 1999, MNP changed the limitations of the park and this part of the buffer zone was merged into the strict PA zone. The gendarmes came to evict residents from their homes and relocated them to the area where the village of Amboditanimena is now located. Currently, the village has no real buffer zone separating it from the PA and thus it has no right to harvest from the surrounding forests.

At the eastern side of the PA, all study villages apart from one (Manokoakora, which is further away from the PA) have forest fragments near PA border that are controlled by the Chef Forestier who operates under the Ministry of Environment and Forests. Local people are allowed to log on the hillsides, but only up to a certain altitude, as hilltops must always be left untouched (according to the law and enforced by the Chef Forestier). The topography of the eastern region is very steep and fertile lowland is limited causing pressure to expand cultivations higher uphill. As almost no forest remains in the valleys, people have to buy logging permissions from the Chef Forestier if they need wood - a process described by local villagers as difficult and expensive. This results in many hill tops becoming bare and illegal logging and burning continuing throughout the region.

NATURAL RESOURCES MANAGEMENT AT THE COMMUNITY

LEVEL. All study villages have a set of fady or taboos that serve to guide the harvesting and use of some species. For example, in Amboditanimena, crayfish cannot be caught for

Table 1. Study villages. (Number of inhabitants, CVB 2013)

\begin{tabular}{|c|c|c|c|}
\hline Name & $\begin{array}{c}\text { Nbr of } \\
\text { inhabitants }\end{array}$ & $\begin{array}{c}\text { Ethnic } \\
\text { group }\end{array}$ & Nearest forested area \\
\hline Vohiparara & 325 & Betsileo & Community-managed forest \\
\hline Amboditanimena & 240 & Betsileo & $\begin{array}{c}\text { Located directly at the RNP border } \\
\text { with no buffer forest }\end{array}$ \\
\hline Manokoakora & 550 & Tanala & No remaining forest near the village \\
\hline Ranovao & 341 & Tanala & Buffer zone / forest fragments \\
\hline Torotosy & 286 & Tanala & Buffer zone / forest fragments \\
\hline Ambatolahy & 265 & Tanala & Buffer zone / forest fragments \\
\hline
\end{tabular}


commercialisation, only for self-subsistence. However, in almost all study villages, the interviewees told us that they do not have any community-based rules or norms for the use of land and its species. More detailed studies on traditional environmental knowledge have observed these fady to be losing their relevance in local people's lives and local natural resources management (see Jones et al. 2008). Indeed, the laws prohibiting burning and gathering are repeated in the interviews much more often when the question is about land and resource use rules. Even though fady and other community-based norms exist, most of our informants did not regard them as rules for natural resources management in the same way, for instance, as national laws are seen. Essentially, there seem to be two systems of norms in place, i.e., local norms and national laws, and while potentially working towards the same goal, the two do not currently benefit or strengthen one another.

Similarly, the RNP authority that we interviewed does not mention any community-based or traditional natural resources management practices that could support conservation (Expert interview 3). The expert from CVB confirms the same perception that the traditional culture and values that used to shape local natural resource governance regimes have been lost (Expert interview 2), having been replaced by external rules and western education. Ultimately, increasing poverty has also made the compliance to fady difficult especially if and when such compliance compromises everyday needs such as food. CVB and RNP have started offering environmental education and livelihood diversification projects in the local communities. The MNP authority argued that local communities have enough land to feed each household; the problem lies in unsustainable management practices and lack of local initiative (Expert interview 3). Yet, as mentioned above, most of the communities around RNP lack management authority over their surrounding forests.

From our CVB informant, we heard that particularly the Tanala are living in "isolation and ignorance" of environmental issues (Expert interview 2). Tanala livelihoods have traditionally been based on forest product gathering rather than agriculture, and CVB practitioners have found it extremely difficult to teach them new agricultural methods. The situation is further challenged by there being far less cultivable low land in the area inhabited by the Tanala than in the Betsileo area. The latter are described as more hard-working, active and open to new influences, and the agriculture development projects implemented to date have been more successful with them than with the Tanala.

Vohiparara is the only study village that is slightly exceptional with regards to community-based management, as it has the community-managed forest. The villagers seem to be very proud of their forest, which they tell is growing in size. As one informant told us: 'I think that maybe the whole life of this village depends of our forest.' (Community member, Vohiparara).

Villagers harvest wood from their forest for construction and fire. The only products gathered for commercialisation are honey and crayfish. The village chief has the formal authority to control the use of the community forest, but according to a key informant, management is mostly based on informal social control: if someone takes more than needed, others in the community will reproach them. Also, all major activities in the forest, such as cutting trees, require rituals that are performed collectively. The crayfish catching offers an example of community-based natural resources management: since the villagers have observed that the crayfish population in their forest has become very young, the community has agreed to pause harvest until the population gains age.

In each of the study villages, we found local people showing strong attachment to the land, both as their ancestral land to which they have strong cultural bonds, as well as their only asset from which to derive their livelihood. Whenever outsiders come in to log or mine gold in the buffer forest surrounding villages, the local villagers stated that they attempt to stop them. In such situations, the local communities have managed to get help from local authorities, namely the Chef Forestier, MNP, or the mayor, and have in most cases succeeded to keep the outsiders from harvesting.

In all but one study village (Vohiparara), several interviewees questioned the necessity of the PA, stating that it is not their traditional way of life that causes deforestation and that they do not need the PA to protect their forest. As one informant told us: 'We always protected the forest, but now the national park has taken from us the right to protect it and to take benefits from it. Way back people shared the forest and everyone was responsible for their own actions. We used to collect honey, crayfish, and keep zebus there. We also enjoyed walking in the forest. We still could go there but people do not go often anymore because they are afraid. RNP agents have told us that cutting a tree is like killing a person and exploiting the forest will be heavily punished.' (Community member, Torotosy). Hence, as seen in this case, even when local community rights to participate in decision-making are not recognised, local people continue to have a strong sense of ownership of, and belonging to, the land. They also reflect an opposition to the "exploiter" role that they feel they are given by conservation authorities.

SOCIAL IMPACTS OF CONSERVATION. The way local villagers

feel about national laws regulating forest use was found to be a contested and conflictive issue in the communities we studied. In Torotosy, interviewees report that some villagers turn each other in to the authorities, namely to the Chef Forestier, for the illegal activities they have carried out, resulting in sanctions to the wrong-doers. Below, we discuss the possible reasons for this. Meanwhile, in Manokoakora, many villagers who take part in the popular community association for conservation, reforestation, and agricultural development advocate for abandoning tavy leading to frequent conversations and debates with those community members who want to continue the traditional practice. The laws on burning (i.e., those setting the limits and safer practices for burning) have offered guidelines by which tavy can be done within limits that community members can agree on, to some extent, but the argument is still ongoing. It is mostly members of local park patrolling committees who get paid by MNP (at least in Torotosy) and members of the community association, i.e., landowners (as in the case of Manokoakora), who advocate this shift away from tavy. In other words, these wealthier individuals can perhaps afford to lessen or altogether abandon tavy, as they can afford to meet their food needs in other ways while turning to promote conservation action instead. Meanwhile, poorer families may be left with no other option than to slash-and-burn.

Park patrolling committees (Comité Local du Parc, CLP) are an interesting example of how an attempt towards more participatory conservation may turn out to have unexpected social impacts. MNP defines patrolling as a form of co-management with 
communities (MNP 2014) and in the interview with the MNP authority, patrolling was indeed the only concrete form of collaboration that was mentioned (Expert interview 3). Patrolling is carried out by CLP'S that are founded in 47 communities around the park. Each participant is paid a daily salary by MNP for the patrolling operations that MNP organises irregularly (confirmed also in Expert interviews 3 and 5). From the point of view of a local villager, the membership in CLP might be a way of getting involved in conservation but, importantly, it also means an income opportunity, albeit an unreliable and sporadic one.

In two of the study villages, Vohiparara and Torotosy, some of the young men take part in the CLP and patrol the forest with a mixed brigade of local gendarmerie, police, and army personnel looking out for - and arresting - individuals who carry out illegal activities within the park (Expert interview 5). The problem is what happens when the patrolling is over and the mixed brigade are gone. As one local community patroller shared: 'The problem is that the criminals are armed and as they recognise the faces of CLP members they might take revenge. There is a tension between the villagers of Vohiparara and the criminals. There have been no attacks so far but CLP members are afraid because the criminals keep following them. They do not dare to go to the market for instance.' (Community member, Vohiparara).

At the Betsileo side of the PA, the majority of arrests concern artisanal gold mining by unorganised individuals, driven to this activity by sheer hunger and poverty (Expert interview 5). At the Tanala side, tavy practised by the local community members is keeping the authorities and CLP busy. One striking example of such an arrest is an incident told by a woman who explains that since her husband died, the family has been in trouble due to their desperate need to open new land for cultivation, but being unable to do so as it is considered men's work: 'My son was taken to Ifanadina to be punished for burning. He was only 12 years old and he had done it because he wanted to help his family by creating a small piece of field. He was sentenced to pay a $20000 \mathrm{Ar}$. fine. It was people from both this and the neighbouring village who turned him in.' (Community member, Torotosy).

NEGOTIATIONS BETWEEN THE PA AND LOCAL COMMUNITIES.

The RNP authority emphasised the importance of local communities in shaping conservation outcomes. They explained that the RNP does not have the staff and capacity to control the 41000 hectares of RNP and thus need to collaborate with local communities. Based on their experience they felt that only some, but not all, communities and individuals are motivated to collaborate with the MNP (Expert interview 3).

The literature we reviewed shows that throughout its history, RNP has been managed in a strict top-down fashion. Even though there are some villagers who find the rules of RNP reasonable, the majority we interviewed have difficulties accepting them. In the Tanala villages bordering the PA, the villagers tell that they are so afraid of the Chef Forestier and PA guards that they do not even enter the forest anymore. Meanwhile it is evident that wood (for fuel and building purposes) is still being collected and new fields being opened, despite both activities being illegal. There has even been some small-scale gold mining and harvesting of valuable species to be sold in unofficial markets - both of which have become attractive options for those in desperate need for quick income (Expert interview 2). Such illegal activities are carried out at a great risk, and as described above, arrests are common.
The elders we discussed with shared that the PA borders or rules were never negotiated, and some of them said they feel betrayed by conservation authorities who extracted their local knowledge to later create the PA. The perceived disrespectful role played by MNP and the fact that there has been no local participation in decision-making, trigger very negative attitudes. Also, the majority of local villagers expressed frustration due to having no means to communicate with authorities or to influence the rules that so directly affect their lives. Even though the majority of the interviewees express a will to cooperate with MNP, the problem as expressed by the villagers - is that MNP decides when and how to communicate: 'Sometimes we do some cooperation with MNP. I can only hope that MNP wants to cooperate with us because it is the authority. The villagers always want to hear what MNP has to say.' (Community member, Torotosy).

There are also individuals in each community who want to change the relationship between the communities and MNP - rather than outright rejecting MNP. This viewpoint was especially strongly expressed in Amboditanimena, the village where we had expected the residents to be most resentful towards MNP due to their history of forced physical displacements. Residents of Amboditanimena hope that MNP would be more flexible and negotiate land rights with them but they stress that they have not yet been able to have any discussion with MNP staff.

The lack of perceived participation and communication in the management of RNP has a range of consequences at the local level. The ways in which the rules are negotiated and enforced as well as any contact that local people have with MNP personnel affect local people's sense of being respected and heard, and thus of feeling equal in the playing field. The extent to which the rights and human dignity of local people are respected ultimately defines whether they are likely to develop a feeling of ownership of a new project (such as managing a PA), and thereby also view the related rules as legitimate. On the contrary, we found an array of strong reactions to the imposed rules of RNP and the ways in which they are being enforced (Supplementary Material).

Even though some individuals in a few communities may gain some short-term benefits, the majority of our interviewees express dissatisfaction with the PA. Local reactions range from passive denial of problems, and fear to challenge the authorities, to active attempts to negotiate with the PA authorities or intentionally disobeying the rules. MNP is facing even direct opposition in the form of armed conflicts (Expert interview 1) in the areas that we were not able to visit, the latter for obvious safety reasons.

Drawing from the multitude of reactions that the current topdown conservation strategy triggers in RNP, we see yet another case of local community subordination, and a power dynamic where local people are too afraid to speak up or to try to influence change. The lack of means to influence or forums to discuss makes local people feel powerless and a part of them become passive and seem to opt for denying some problems rather than trying to change them. A similar hierarchical power structure can be seen in the donor-recipient relationship of the development programs and sporadic employment offered to communities by MNP. Decades of supervision and assistance have led many community members to passively await and expect outside intervention to solve their problems for them, rather than initiate solutions themselves. Over the years, the development projects that MNP and others have offered to local communities have been punctual, targeted, and short-term, creating few sustainable impacts 
and unevenly distributed benefits among villages, as explained by the MNP authority and the representatives of the Association of Guides of RNP (Expert interviews 3 and 4). Communities have come to expect financial aid and employment from MNP, revealing a situation of dependence. Furthermore, the MNP authority stated that the lack of trust that local communities have towards MNP is one of the biggest challenges for conservation.

The most positive perceptions on cooperation with MNP were in Vohiparara, which is also the only village with its own designated community forest. On the one hand, the villagers in Vohiparara are actively involved with conservation activities, have personal contacts with MNP staff, and speak proudly of the good relations with MNP and the help they have received. Yet, on the other hand, they tell about the ongoing conflict with MNP over crayfish catching: they would like to catch crayfish inside the protected area while the population in their own forest is recovering (and ideally alternate between the two in the long-term future, to keep both populations stable). The propositions by local community members for solving the problem included founding a community association for regulating crayfish catching and reporting to MNP. This concrete example reflects a willingness to take initiative, something which this study did not find in the other study villages.

\section{DISCUSSION}

Despite the official "co-management policy" of MNP (MNP 2014), some communities of Ranomafana region report that they are seldom recognised or treated as critically important partners in conservation. This has important consequences on the relationships between MNP and local communities, as well as on the legitimacy of the PA as a whole, and hence also the ultimate likelihood of successful conservation outcomes in the area.

Our findings are in line with previous research in the area (e.g., Korhonen 2006), firstly in that the conservation restrictions imposed by MNP and the Chef Forestier have hit the local communities hard, especially those who were already marginalized, i.e., remote, landless, and asset-poor (Kari and Korhonen-Kurki 2013). Secondly, long-term vulnerability threatens to push these villagers further into the margins of society, with development projects doing little if anything to improve their situation (Peters 1999). Ecotourism has provided employment only for a few, having little effect on local livelihoods (Sarrasin 2013). Consequently, local vulnerability is on the increase and traditional institutions of natural resource management are breaking down (Jones et al. 2008) both processes accelerating unsustainable land-use practices.

Our interview data show that the imposed rules and regulations and the authorities enforcing them are mostly seen as illegitimate in the eyes of local communities, similar to other studies (also Peters 1999, Kull 2002). As we have shown above, the reactions to top-down governance are varied and have already led to mistrust and even direct opposition on behalf of local villagers. In parallel, decades of unsustainable development projects and insufficient compensation have led to scepticism. The attempted development projects, environmental awareness raising, and attempts to involve local people in conservation by giving them work in patrolling are all carried out in this context of confused and often even resentful feelings towards the PA and its agents. On one hand, local communities are accustomed to wait for outside intervention and financial aid while, on the other hand, as long as communication is hampered and local communities' rights overlooked, the latter find it hard to trust outside interventions, let alone take ownership of them. Similarly, as long as local traditional management practices and culture are disregarded, any externally initiated and imposed projects are likely to be held as just that: external and unlikely to result in genuine partnership or mutual understandings.

Taking into account all the above, conservation policy would benefit from embracing a more legitimate and representative form of governance - one that the local communities approve of and respect. This requires a commitment to social justice (Fortwangler 2003) and conservationists would do well to take advantage of the theory of environmental justice and adopt its three main principles: (i) equity of risks and benefits, (ii) recognition of rights, and (iii) participation in decision-making (Schlosberg 2013). The MNP authority we interviewed claimed to understand the lack of trust held by local communities due to the insufficient compensation they receive, but did not see its relation to the lack of recognition or participation given to local communities by authorities. The need to improve communication (as stressed by many local interviewees) was not raised as a concern by the MNP authority - nor was any possibility of increasing local participation or ownership. The MNP representative did stress the importance of collaboration with local communities, but only mentioned employment of local people in patrolling activities as a means for doing so.

Local involvement in the patrolling of the PA has not created a partnership between MNP and local communities and cannot be used as an indicator of co-management, contrary to the anticipation of MNP. However it does create new realities on ground. Gezon (2006) shows a similar dynamic in an Antankarana community neighbouring a PA in the northern Madagascar. The community members who are hired by conservation authorities face a situation where they have commitments to multiple, conflicting sources of authority, from the formal legislation and foreign conservation norms to local kinship ties. Ultimately, CLP members have to choose between these commitments. In some cases, turning against members of their own or neighbouring communities, can provide individual short-term benefits, but at the cost of social cohesion and solidarity. In other words, those with additional sources of income (e.g., from work in the CLP) and thus with more options to gain their living can turn the "wrong-doers" in. The socalled "criminals" on the other hand are mostly people who are driven to illegal activities because of extreme poverty and desperation, although in some instances also due to resentment towards MNP (see also e.g., Twinamatsiko et al. 2014). This dynamic enforces the existing inequalities in and among local communities, pushing the already less-endowed individuals and households further into the margins of the society (see also Brockington 2004). It also creates tensions and fear of revenge among villagers, as well as between villages and park managers, and increases the overall underlying insecurity experienced by the local villagers.

Another point of concern is that of local natural resources management and the possibilities it could offer for cooperation to achieve both conservation goals and social sustainability. Scholars specialised in the topic have suggested that the integration of traditional norms in conservation in post-colonial contexts is key to providing non-costly, voluntary, and respectful conservation approaches (Colding and Folke 2001). Yet, at least according to some of our interviewed local experts there is no such traditional, sustainable natural resources management system in place in the 


\section{context of RNP.}

Based on our village-level data, however, we found that there still are at least some specific fady (i.e., local taboos) regulating the use of certain species. As has been noted elsewhere, traditional taboos rarely originate from attempts to sustainably manage natural resources (Berkes 2004, Jones et al. 2008) and indeed, the interviewees do not see fady as having much to do with conservation or natural resources management (see also Osei-Tutu et al. 2014). As Ostrom (1990) has pointed out in her influential work on local institutions, the maintenance of local informal institutions (for regulating the use of land and species sustainably and equitably among community members) depends on the recognition of local management authority. One cannot assume that a set of local management institutions would be maintained if and when they are rendered irrelevant or unnecessary due to the management authority being taken up by central government, as has been the case in RNP.

In addition to the national laws, traditional natural resources management systems are further replaced by environmental awareness raising that is based on scientific and neoliberal world views (as found in other studies, e.g., Jones et al. 2008, Hanson 2012, Miller et al. 2014). In this discourse, local knowledge is regarded as something irrelevant, something that does not overlap with or contribute to the conservation laws, and the local people are thus forced to see themselves as a threat to the environment. As Igoe and Brockington (2007) conclude, this kind of disrespect, dismantling of local natural resources management traditions and criminalisation of local livelihoods compromise the very citizenship of local communities.

This, however, does not mean that the local communities cease to influence conservation. On the contrary, we witnessed a lively debate on land-use practices within and among local communities and with a range of external actors. Our study also provides evidence for how a community - in this case Vohiparara was able to take a more active role in managing a forest area despite the PA restrictions. On the one hand, the interviewees in Vohiparara speak proudly of the good relations with MNP and the help they have received, on the other hand they tell about the ongoing conflict with MNP over crayfish catching that they attempt to solve. What might have given this community more initiative than other communities lay beyond the scope of this research. However, one explanation might be the historical opposition and relation vis-à-vis MNP, which might have led to a more frequent, prioritised and eventually fluent communication between the community and MNP. This, in turn has possibly led to stronger community self-esteem, more courage and skills to confront problems, and therefore overall a more active community. This question cannot be answered based on the available data but it poses a fundamental and important question for future research attempting to investigate ways for more bottom-up initiative, and for promoting stronger and more equitable and genuine partnerships between local communities and national park (and other) authorities.

LIMITATIONS OF THE STUDY. The sample of local communities examined in this study are located within a day's walk from the main road and relatively close to the town of Ranomafana where the PA administration is based. Therefore, we can expect these communities to be more exposed to conservation authorities, better aware of MNP and its conservation strategies, and also at the receiving end of more environmental education and development programs than the more remote villages. Considering this, we find it alarming that even in our sample villages our informants claimed that there is no communication or negotiation with MNP.

Another limitation is the small sample size of interviewees. One of the main remarks of our study is the variety of different attitudes and reactions to conservation policies even within a community. While the answers of the interviewees started to repeat themselves indicating reaching the saturation point - at least in some of the study communities - we can still assume that having more data from each village could have revealed even more variety and social dynamics.

Choosing only villages near Ranomafana town was not our initial intention for this study. However, we were forced to leave out more remote villages due to logistical and temporal limitations and also due to some unexpected political events of unrest that prohibited us from going to certain areas. We acknowledge that having left out some of the more remote villages brings a geographical bias to the study, and also limits the range of information and characteristics that we would likely have obtained had we included them. For instance, our study villages have far better access to markets, which almost certainly plays a key role in determining livelihood opportunities and therefore also the types and levels of pressures placed on natural resources.

\section{CONCLUSION}

Our study examined institutional arrangements and community involvement of biodiversity conservation in Ranomafana National Park, with the aim of assessing local communities' involvement and initiative in conservation planning and management. We identified several tensions that exist between conservation authorities and local communities, as found elsewhere, also in continental Africa (Pyhälä et al 2016). The analysis of data gathered in the communities around RNP reveals that natural resource management takes place within a complex set of formal and informal institutions and sources of authority and dynamics among different social groups and actors at many levels. Conservation policies provoke a wide range of diverse local reactions, affecting the extent to which communities are willing (or able) to cooperate with conservation authorities.

It is evident that the historical oppression of communities around Ranomafana has resulted in a burden that challenges any new and more participatory conservation initiatives in the area. This burden influences both sides, i.e., communities and authorities. Local communities are sceptical of new conservation and development initiatives and therefore try to take all the material benefit from them while they last rather than self-organise or design structures for long-term sustainability themselves, let alone take ownership of the projects. Meanwhile, conservation authorities continue to blame local people's ignorance for the continuing deforestation and are reluctant to handover any trust or responsibility to them - despite local pro-conservation interests and practices. This, in turn, means that the so called "co-management" effort, as well as any environmental awareness raising, is likely to be conducted in a non-genuine manner, and therefore likely to only further exacerbate feelings of resentment among local communities. The result is a vicious cycle of mistrust and disrespect on both sides which, over time and generations, is difficult to break. 
While community participation is critical, our results indicate that communities are rarely harmonious, homogeneous units and therefore participatory conservation policies and related development projects also do not automatically treat all community members equally or address inter-community problems, as other scholars have also pointed out (Agrawal and Gibson 1999, Leach et al. 1999, Castro and Neilson 2001). As Gezon (2006) argues, conservation projects can either reinforce existing power asymmetries or empower marginalised segments of the population. Our results seem to support the former, resulting in the further subordination and marginalisation of the already weakest social groups. MNP and all development and conservation actors should take this into account when planning and executing their projects, as the unequal effects threaten both social and ecological outcomes of existing policy. If current conservation and development strategies claim to aim at enhancing local livelihoods, they might do better if they prioritised targeting the poorest of the society, i.e., the ones most dependent on forest resources and therefore most easily driven to carry out sporadic illegal activities in the PA.

This case study strongly supports the already existing literature arguing against top-down conservation models in that they fail to support well-being and equity of local communities and to gain community approval. On the other hand, it also shows evidence of how the PA-community relationship can be different, especially if set in a more positive and constructive tone, as we found in one of our case study villages, where villagers have managed to keep their own community forest and seem to actively cooperate with and challenge MNP. We urge further research to look closer at these dynamics, and particularly address the question of why some communities (like Vohiparara) hold and act upon more self-initiative than other communities.

Empowerment of local communities to take initiative and to self-organise for better management of their natural resources requires some authority over those resources (Ostrom et al. 1999). Where that authority lies is perhaps the key questions, and the results of our study indicate that at least some degree of autonomy could boost community self-esteem, self-initiative, interest and ownership, and thereby also community self-organisation. Only once communities have met conservation authorities at such a half-way point can a real mutual partnership even be conceived.

\section{ACKNOWLEDGEMENTS}

This research was funded by the Madagascar project of the Global Change and Conservation team from the University of Helsinki. We would like to give special thanks to Mar Cabeza for providing the research opportunity within the RESPECT (Reserve Planning in the Tropics) exchange field course in Ranomafana, and Álvaro Fernandez-Llamazares for providing some of the focus group data for our study. We also thank two malagasy students for translation, Tafita Rakotoarimanana and Maria Hariniaina, both from the University of Antananarivo.

\section{REFERENCES}

Adams, W. M. and Hutton, J. 2007. People, parks and poverty: political ecology and biodiversity conservation. Review. Conservation and Society 5, 2: 147-183.

Agrawal, A. and Gibson, C.C. 1999. Enchantment and disenchantment: the role of community in natural resource conservation. World Development 27, 4: 629-649. (doi:10.1016/S0305-750X(98)00161-2)

Agrawal, A. and Redford, K. 2009. Conservation and displacement: an overview. Conservation and Society 7: 1-10. (doi:10.4103/0972-4923.54790)
Balée, W. 1994. Footprints of the Forest: Ka'Apor Ethnobotany: The Historical Ecology of Plant Utilization by an Amazonian People. Columbia University Press, New York.

Barrett, C. B., Brandon, K., Gibson, C. and Gjertsen, H. 2001. Conserving tropical biodiversity amid weak institutions. Bioscience 51, 6: 497-502. (doi:10.1641/0006-3568(2001)051[0497:CTBAWI]2.0.CO;2)

Bazeley, P. 2013. Qualitative Data Analysis: Practical Strategies. Sage Publications, London.

Berkes, F. 2004. Rethinking community-based conservation. Conservation Biology 18, 3: 621-630. (doi:10.1111/j.1523-1739.2004.00077.x)

Brechin, S. R., Wilshusen, P. R., Fortwangler, C. L. and West, P. C. 2002. Beyond the square wheel: toward a more comprehensive understanding of biodiversity conservation as social and political process. Society and Natural Resources: An International Journal 15(1): 41-64.

Brockington, D. 2002. Fortress Conservation: The Preservation of the Mkomazi Game Reserve, Tanzania. Indiana University Press, Bloomington.

Brockington, D. 2004. Community conservation, inequality and injustice: myths of power in protected area management. Conservation \& Society 2, 2: 411-432.

Brockington, D., Igoe, J. and Schmidt-Soltau, K. 2006. Conservation, human rights, and poverty reduction. Conservation Biology 20, 1: 250-252. (doi:10.1111/j.1523-1739.2006.00335.x)

Brosius, J. P. and Russell, D. 2003. Conservation from above: an anthropological perspective on transboundary protected areas and ecoregional planning. Journal of Sustainable Forestry 17, 1-2: 39-65. (doi:10.1300/J091v17n01_04)

Castro A. P. and Neilson, E. 2001. Indigenous people and co-management: implications for conflict management. Environmental Science and Policy 4, 4-5: 229-239. (doi:10.1016/\$1462-9011(01)00022-3)

Colding, J. and Folke, C. 2001. Social taboos: "Invisible" systems of local resource management and biological conservation. Ecological Applications 11, 2 : 584-600. (doi:10.1890/1051-0761(2001)011[0584:STISOL]2.0.CO;2)

Cox, P.A. and Elmqvist, T. 1997. Ecocolonialism and indigenous-controlled rainforest preserves in Samoa. Ambio 26, 2: 84-89.

CVB (Centre ValBio). 2013. Rapport Annuel 2012 sur les Activités Relatives à I'Éducation Sanitaire. Tomady / Centre ValBio.

Ferraro, P. J. 2002. The local costs of establishing protected areas in low-income nations: Ranomafana National Park, Madagascar. Ecological Economics 43, 2-3: 261-275. (doi:10.1016/S0921-8009(02)00219-7)

Fortwangler, C. L. 2003. The winding road: incorporating social justice and human rights into protected area policies. In: Contested Nature: Promoting International Biodiversity Conservation with Social Justice in the TwentyFirst Century. S. R. Brechin, C. L. Fortwangler, P. R. Wilshusen and P. C. West (eds.), pp 25-40. Sunny Press, Albany, NY.

Geldmann, J., Barnes, M, Coad, L., Craigie, I. D., Hockings, M. and Burgess, N. D. 2013. Effectiveness of terrestrial protected areas in reducing habitat loss and population declines. Biological Conservation 161: 230-238. (doi:10.1016/j.biocon.2013.02.018)

Gezon, L. L. 2006. Global Visions, Local Landscapes: A Political Ecology of Conservation and Control in Northern Madagascar. AltaMira Press, Lanham, $\mathrm{MD}$.

Hanson, P. W. 2012. Toward a more transformative participation in the conservation of Madagascar's natural resources. Geoforum 43, 6: 1182-1193. (doi:10.1016/j.geoforum.2012.03.005)

Igoe, J. and Brockington, D. 2007. Neoliberal conservation: a brief introduction. Conservation and Society 5, 4: 432-449.

Jones, J. P. G., Andriamarovololona, M. M. and Hockley, N. 2008. The importance of taboos and social norms to conservation in Madagascar. Conservation Biology 22, 4): 976-986. (doi:10.1111/j.1523-1739.2008.00970.x)

Kari, S. and Korhonen-Kurki, K. 2013. Framing local outcomes of biodiversity conservation through ecosystem services: a case study from Ranomafana, Madagascar. Ecosystem Services 3: e32-e39. (doi:10.1016/j.ecoser.2012.12.003)

Korhonen, K. 2006. The Rocky Road of Social Sustainability. The Impact of Integrated Biodiversity Conservation and Development on the Local Realities in Ranomafana National Park, Madagascar. Unpubl. Ph.D. thesis, University of Helsinki, Finland. Available at <goo.gl/ZtxE2D> 
Kothari, A., Camill, P. and Brown, J. 2013. Conservation as if people also mattered: policy and practice of community-based conservation. Conservation and Society 11, 1: 1-15. (doi:10.4103/0972-4923.110937)

Kull, C. A. 2002. Empowering pyromaniacs in Madagascar: ideology and legitimacy in community-based natural resources management. Development and Change 33, 1: 57-78. (doi:10.1111/1467-7660.00240)

Laurence W. F., Useche,D. C., Rendeiro, J., Kalka, BM., radshaw, C. J. A., et al. 2012. Averting biodiversity collapse in tropical forest protected areas. Nature 489: 290-294. (doi:10.1038/nature11318)

Leach, M., Mearns, R. and Scoones, I. 1999. Environmental entitlements: dynamics and institutions in community-based natural resource management. World Development 27, 2: 225-247. (doi:10.1016/S0305-750X(98)00141-7)

Maffi, L. 2005. Linguistic, cultural, and biological diversity. Annual Review of Anthropology 34: 599-617. (doi:10.1146/annurev.anthro.34.081804.120437)

Martinez-Alier, J. 2013. The environmentalism of the poor. Geoforum 54: 239-241. (doi:10.1016/j.geoforum.2013.04.019)

Miller, B., Soulé, M. E. and Terborgh, J. 2014. 'New conservation' or surrender to development? Animal Conservation 17, 6: 509-515. (doi:10.1111/acv.12127)

MNP (Madagascar National Parks). 2014. Madagascar National Parks Protected Areas Network, Strategic Management Plan 2014-2024. Madagascar National Parks.

Mombeshora, S. and Le Bel, S. 2009 Parks-people conflicts: the case of Gonarezhou National Park and the Chitsa community in south-east Zimbabwe. Biodiversity and Conservation 18, 10: 2601-2623. (doi:10.1007/s10531-009-9676-5)

Myers, N., Mittermeier, R.A., da Fonseca, G.A.B. and Kent, J. 2000. Biodiversity hotspots for conservation priorities. Nature 403: 853-858. (doi:10.1038/35002501)

Naughton-Treves, L., Buck Holland, M. and Brandon, K. 2005. The role of protected areas in conserving biodiversity and sustaining local livelihoods. Annual Review of Environment and Resources 30: 219-252. (doi:10.1146/annurev.energy.30.050504.164507)

Osei-Tutu, P., Pregernig, M. and Pokorny, B. 2014. Legitimacy of informal institutions in contemporary local forest management: insights from Ghana. Biodiversity and Conservation 23, 14: 3587-3605. (doi:10.1007/s10531-0140801-8)

Ostrom, E. 1990. Governing the Commons: The Evolution of Institutions for Collective Action. Cambridge University Press, Cambridge.

Ostrom, E., Burger, J., Field, C.B., Norgaard, R.B. and Policansky, D. 1999. Revisiting the commons: local lessons, global challenges. Science 284, 5412: 278-282. (doi:10.1126/science.284.5412.278)

Peters, J. 1998. Transforming the integrated conservation and development project (ICDP) approach: observations from the Ranomafana National Park Project, Madagascar. Journal of Agricultural and Environmental Ethics 11, 1: 17-47. (doi:10.1023/A:1007796628731)

Peters, J. 1999. Understanding conflicts between people and parks at Ranomafana, Madagascar. Agriculture and Human Values 16, 1: 65-74. (doi:10.1023/A:1007572011454)

Pyhälä, A., Osuna Orozco, A. and Counsell, S. 2016. Protected Areas in the Congo Basin: Failing both People and Biodiversity? Rainforest Foundation UK London. Available at <http://www.mappingforrights.org/files/38342 Rainforest-Foundation-Conservation-Study-Web-ready.pdf>

Redford, K. H. and Stearman, A. M. 1993. Forest-dwelling native Amazonians and the conservation of biodiversity: Interests in common or in collision? Conservation Biology 7, 2: 248-255. (doi:10.1046/j.1523 1739.1993.07020248.x)

Robbins, P. 2012. Political Ecology: A Critical Introduction, 2nd Edition. WileyBlackwell.

Sarrasin, B. 2013. Ecotourism, poverty and resources management in Ranomafana, Madagascar. Tourism Geographies 15, 1: 3-24. (doi:10.1080/14616688.2012.675512)

Scales, I. R. 2014. The future of conservation and development in Madagascar: time for a new paradigm? Madagascar Conservation \& Development 9, 1 : 5-12. (doi:10.4314/mcd.v9i1.2)
Schlosberg, D. 2013. Theorising environmental justice: the expanding sphere of a discourse. Environmental Politics 22, 1: 37-55. (doi:10.1080/09644016.2013.755387)

Schwartzman, S. and Zimmerman, B. 2005. Conservation alliances with indigenous peoples of the Amazon. Conservation Biology 19, 3: 721-727. (doi:10.1111/j.1523-1739.2005.00695.x)

Twinamatsiko, M., Baker, J., Harrison, M., Shirkhorshidi, M., Bitariho, R., et al. 2014 Linking Conservation, Equity and Poverty Alleviation: Understanding Profiles and Motivations of Resource Users and Local Perceptions of Governance at Bwindi Impenetrable National Park, Uganda. IIED Research Report, London. Available at <http://pubs.iied.org/pdfs/14630IIED.pdf>

Vermeulen, S. and Sheil, D. 2007. Partnerships for tropical conservation. Oryx 41, 4: $434-440$.

Watson, J. E. M., Dudley, N., Segan, D. B. and Hockings, M. 2014. The performance and potential of protected areas. Nature 515: 67-73. (doi:10.1038/nature13947)

West, P., Igoe, J. and Brockington, D. 2006. Parks and peoples: the social impact of protected areas. The Annual Review of Anthropology 35: 251-277. (doi:10.1146/annurev.anthro.35.081705.123308)

World Bank. 2016. Data by topic. <http://data.worldbank.org/topic> accessed on 20 April 2016.

\section{SUPPLEMENTARY MATERIAL.}

Available online only.

Table S1. Summary of the data gathered in November-December 2014.

Table S2. Local reactions to top-down rules. 
Vuola, M. and Pyhälä, A. 2016. Local community perceptions of conservation policy: Rights, recognition and reactions. Madagascar Conservation \& Development 11, 2: 77-86.

http://dx.doi.org.104314/mcd.v11i2.6 Supplementary Material

Table S1. Summary of the data gathered in November-December 2014.

\begin{tabular}{|c|c|c|}
\hline Method & $\begin{array}{l}\text { Sample } \\
\text { size }\end{array}$ & Focus of data \\
\hline Household interviews & 44 & $\begin{array}{l}\text { FPIC; local perceptions on RNP and forests;, } \\
\text { livelihoods; socio-ecological change; development } \\
\text { projects; rules and regulations; relationship with } \\
\text { authorities }\end{array}$ \\
\hline Village meetings & 5 & Introductions; FPIC; village-level priority issues \\
\hline Key informant interviews & 5 & $\begin{array}{l}\text { Externally-initiated conservation projects in the } \\
\text { community; relationship with different authorities }\end{array}$ \\
\hline Focus groups & 3 & $\begin{array}{l}\text { Perceptions of men, women and elders on } \\
\text { conservation }\end{array}$ \\
\hline $\begin{array}{l}\text { Internal Documents (e.g., Centre ValBio - } \\
\text { CVB, Outreach programs, etc) }\end{array}$ & $\begin{array}{l}\text { Annual } \\
\text { reports } \\
2006,2010\end{array}$ & General village information \\
\hline Participant Observation & $\begin{array}{l}\text { In all } \\
\text { sample } \\
\text { villages }\end{array}$ & $\begin{array}{l}\text { Validation and deepening our understanding of } \\
\text { the way of life and the socio-environmental setting }\end{array}$ \\
\hline $\begin{array}{l}\text { Expert interview 1: CVB, Monitoring and } \\
\text { Partnerships Department }\end{array}$ & 1 & $\begin{array}{l}\text { Introduction to the area, current events and } \\
\text { conflicts }\end{array}$ \\
\hline $\begin{array}{l}\text { Expert interview 2: CVB, Conservation } \\
\text { education \& Outreach Department }\end{array}$ & 2 & $\begin{array}{l}\text { Environmental education and agricultural training } \\
\text { programs of CVB; Cultural challenges of } \\
\text { conservation }\end{array}$ \\
\hline $\begin{array}{l}\text { Expert interview 3: Madagascar National } \\
\text { Parks - MNP, Ranomafana National Park - } \\
\text { RNP }\end{array}$ & 1 & $\begin{array}{l}\text { RNP's relation to local communities, policy on } \\
\text { compensation, employment of local people, local } \\
\text { people's demands for land }\end{array}$ \\
\hline $\begin{array}{l}\text { Expert interview 4: Association of Guides of } \\
\text { RNP (Association des Guides de RNP), two } \\
\text { representatives }\end{array}$ & 1 & Benefits of RNP for local communities \\
\hline $\begin{array}{l}\text { Expert interview 5: Gendarmerie of } \\
\text { Vohiparara }\end{array}$ & 1 & $\begin{array}{l}\text { Cooperation of gendarmerie with MNP and local } \\
\text { associations }\end{array}$ \\
\hline
\end{tabular}


Vuola, M. and Pyhälä, A. 2016. Local community perceptions of conservation policy: Rights, recognition and reactions. Madagascar Conservation \& Development 11, 2: 77-86.

http://dx.doi.org.104314/mcd.v11i2.6 Supplementary Material

Table S2. Local reactions to top-down rules.

\begin{tabular}{|c|c|c|}
\hline Reaction & Description & Example of individual or specific expression \\
\hline \multirow[t]{2}{*}{ Approval of rules } & $\begin{array}{l}\text { Distance to PA makes rules } \\
\text { irrelevant; }\end{array}$ & $\begin{array}{l}\text { There are good things. Forest protection } \\
\text { guarantees pure air and water for us. Also } \\
\text { sometimes MNP offers our son work such as } \\
\text { building tracks in the park." - Woman } 58 \text {, Torotosy }\end{array}$ \\
\hline & $\begin{array}{l}\text { Economic benefits gained from } \\
\text { MNP exceed losses }\end{array}$ & \\
\hline Disapproval of rules & $\begin{array}{l}\text { MNP is seen as unjust, } \\
\text { untrustworthy, disrespectful, and } \\
\text { unconcerned for local community } \\
\text { rights and wellbeing }\end{array}$ & $\begin{array}{l}\text { "The national park betrayed us." - Man } 77 \text {, } \\
\text { Ranovao }\end{array}$ \\
\hline \multirow{3}{*}{ Reluctant Obedience } & $\begin{array}{l}\text { Fear for authorities and } \\
\text { punishments }\end{array}$ & $\begin{array}{l}\text { "The villagers are afraid of the authorities and this } \\
\text { is why we obey and do not try to negotiate. But we } \\
\text { are very unhappy." - Man 70, Ranovao }\end{array}$ \\
\hline & No means to negotiate & $\begin{array}{l}\text { "I do not want to change anything because the park } \\
\text { does not bother me. I have no means to complain } \\
\text { so I follow the rules." - Woman } 38 \text {, } \\
\text { Amboditanimena }\end{array}$ \\
\hline & Denial of problems & $\begin{array}{l}\text { "There is no negative side, only that we do not } \\
\text { have enough [resources]to make our living." -Man } \\
55, \text { Amboditanimena }\end{array}$ \\
\hline Attempts to negotiate & $\begin{array}{l}\text { Open argument; propositions for } \\
\text { changing the relationship with } \\
\text { MNP }\end{array}$ & $\begin{array}{l}\text { "In my opinion, a local association should be } \\
\text { established to facilitate things with RNP and } \\
\text { manage crayfish catching in Vohiparara." - Man } \\
\text { 39, Vohiparara }\end{array}$ \\
\hline Disobedience & $\begin{array}{l}\text { Poverty and hunger force people } \\
\text { to illegally use natural resources }\end{array}$ & $\begin{array}{l}\text { "The ordinary people are deprived of their only } \\
\text { livelihood and possessions and they understand } \\
\text { that the law is not on their side but against them." - } \\
\text { Woman } 24, \text { Amboditanimena }\end{array}$ \\
\hline Opposition & Armed conflicts & $\begin{array}{l}\text { Gold mining conflicts between RNP and } \\
\text { northwestern villages }\end{array}$ \\
\hline
\end{tabular}

